\title{
Optimum Board Size to Achieve Optimal Performance in Indonesia*
}

\author{
Komang Ayu KRISNADEWI ${ }^{1}$, Noorlailie SOEWARNO², Dian AGUSTIA ${ }^{3}$
}

Received: August 01, 2020 Revised: September 20, 2020 Accepted: October 05, 2020

\begin{abstract}
The aim of this paper is to review the role of board size as part of the corporate governance system. This paper discusses one aspect of corporate governance, namely, boards, in the Indonesian context. Using the literature review method, this paper explores factors that need to be considered to determine the optimal number of boards, especially in Indonesia. We explore some determinants of board size, such as complexity and leverage, ownership structure, and financial ratio support. The results reveal that an understanding of the differences found in the two-tier board model helps us understand that the different functions of the board of commissioners and the board of directors require different test treatments from countries that adhere to one-tier systems. A review of the relationship between board size and company performance is expected to provide the corporate governance literature with insights into optimizing the sizes of boards that can improve company performance, both in terms of boards of commissioners and boards of directors. This paper proposes the simultaneous testing of board size's relationship with company performance. The results of this study are expected to make a more real contribution about the effect of board size on company performance.
\end{abstract}

Keywords: Board Size, Corporate Governance, Performance, Two-tier, Indonesia

JEL Classification Code: G34, G38, M46, O16

\section{Introduction}

This paper discusses one aspect of corporate governance, namely, boards, in the Indonesian context. As the company management model changes from a classical model to a modern one, the problems faced by a company become increasingly complex. When a company is managed using a

\footnotetext{
*Acknowledgements:

The authors thank Adrian B. Coen as the Proofreader.

${ }^{1}$ First Author. [1] PhD Student, Department of Accounting, Faculty of Economics and Business, Universitas Airlangga, Indonesia. Email: komang.ayu.krisnadewi-2017@feb.unair.ac.id [2] Lecturer, Department of Accounting, Faculty of Economics and Business, Universitas Udayana, Indonesia.

Email: komangayukrisnadewi@unud.ac.id

${ }^{2}$ Corresponding Author. Lecturer, Department of Accounting, Faculty of Economics and Business, Universitas Airlangga, Indonesia [Postal Address: FEB Univ. Airlangga, Jalan Airlangga, Surabaya, East Java, 60286, Indonesia] Email: noorlailie-s@feb.unair.ac.id ${ }^{3}$ Lecturer, Department of Accounting, Faculty of Economics and Business, Universitas Airlangga, Indonesia.

Email: dian.agustia@feb.unair.ac.id

(c) Copyright: The Author(s)

This is an Open Access article distributed under the terms of the Creative Commons Attribution Non-Commercial License (https://creativecommons.org/licenses/by-nc/4.0/) which permits unrestricted non-commercial use, distribution, and reproduction in any medium, provided the original work is properly cited.
}

classical model, its owners and managers decide and enjoy the results of their own decisions. However, in a modern company, there is a separation between the owners and managers of a company. The owner authorizes the manager (agent) to run the company, but demands satisfactory results for the owner (principal). To bridge the interests between the two parties, a board is formed.

According to the decision theory proposed by Fama and Jensen (1983), the board of directors has a role in making decisions and monitoring the implementation of those decisions. In Indonesia, the existing board models have two tiers - the board of directors is formed to take care of the company and take top-level decisions, while the board of commissioners is formed to monitor and provide advice for the board of directors. The role of both is very central to the survival of a company. The rules made to regulate boards in Indonesia comprise the Law of Limited Company Year 2007, the Financial Services Authority Regulation on the Board of Commissioners and Directors in 2014, and are supported by the Guidelines for the Implementation of Corporate Governance in Indonesia issued by the National Committee on Governance Policy (2006).

Related to the optimal size of boards, the rules in Indonesia only state the minimum number of members for a board of commissioners. For public companies, the minimum 
number of commissioners is two people, while the nonpublic minimum is one person. No rule is stated regarding the maximum number, but it is stated that the composition of the board of commissioners must be sufficiently large in view of the complexity of the company's business and in terms of the effectiveness of the decision making process. The rules regarding the size of the board of directors are not explicitly regulated, neither in the Law and Regulations nor in the Corporate Governance (CG) Guidelines.

The differences between the results of studies on the effect of board size on company performance led to this study on the optimal board size and factors that could be used as a basis for determining the number of members on a board. Among them are diversification and leverage, ownership structure, and financial ratios. Based on the results of studies on the effect of board size on performance and the determination of the optimal board size, it can be concluded that there are no definite benchmarks regarding a specific board size that is optimal in terms of optimizing performance.

The rules in Indonesia state that the sizes of boards are adjusted to the complexity of the companies' business with regard to effectiveness in the decision making process. As a business becomes more complex, the number of board members needed may be even greater. On the other hand, the number of board members will trigger the development of the company, meaning that its complexity will also increase. This shows the existence of a reciprocal or simultaneous relationship between board size and company complexity. Therefore, based on the discussion outlined in this paper, one can propose conducting a reciprocal test (for example a simultaneous equation approach) on the relationship between board size and the complexity of the company in subsequent research. The results of this study will contribute to helping corporate governance, in terms of the optimal board size.

\section{Literature Review}

\subsection{Separation of Ownership and Control}

The shift in corporate management patterns, from the management using the classical model to a more modern direction, triggers agency problems (Fama, 1980; Fama \& Jensen, 1983; Jensen \& Meckling, 1976). In company management that uses the classical model (classical entrepreneur firm), the owner of the company doubles as the manager of the company. In this context, the result of all decisions taken by the company manager will be enjoyed by the owner (including the risks). This can be interpreted as the functions related to both the decision maker and the risk guarantor will be carried out by one person (the owner and manager).
However, in line with the development of industry, which has had an impact in terms of the need for additional capital, it has caused the company to seek more modern management. The role of the capital market automatically causes changes in the company's management model. Companies involved in the capital market tend to cause a separation between company managers (decision functions) and company owners. Since the ownership of the company comprises a variety of individuals, the management of the company (the decision-making function) is carried out by the manager. Considering that implementing the decision function is separated from the ultimate risk-bearing function, it is likely to cause issues related to agency problems.

Agency problems arise as a result of the separation between ownership and the risk responsibility function. Because the managers' role is crucial in managing the contracts entrusted to them by the owners, their behavior also plays a role in the survival of their companies. Managerial market mechanisms also help the owner to overcome agency problems. Fama (1980) states that the supply of managerial personnel causes competition between them, meaning they are ultimately required to work better because their payments are revised when goals are not reached.

\subsection{Fama and Jensen's Decision Theory (1983)}

Fama and Jensen (1983) discuss various efforts to overcome agency problems by exploring the understanding of each stage of the decision process. Fama and Jensen stated that, when the ownership and management of the company are in the hands of the same person, then how a decision is taken is not a problem. However, when there is a separation of the two, the agency problems that arise can be overcome by understanding the decision process in an organization. In general, the decision process consists of four stages. First, initiation, namely, proposing various alternative uses of resources. Second, ratification, namely, choosing and deciding on proposals to be implemented. Third, implementation, namely, the carrying out of decisions taken; and finally, monitoring, which measures performance and provides rewards.

These four stages are grouped into two functions: the decision management function, that is to say, the first and third stages; and the decision control, that is to say, the second and fourth stages. To ensure the survival of the organization, when there is a separation of ownership and control, these two different decision functions must be carried out by different agents. Fama and Jensen (1983) found several ways that organizations have used to ensure the implementation of these two different functions. First, the agent at a higher level acts as the executor of the decision control function for the management of the agent's decisions at the lower level (a hierarchical model). Second, there is 
the mechanism of monitoring between agents, which is carried out in an informal manner. And finally, there is the establishment of the board of directors as a mechanism for managing the company, especially in relation to important decision controls (i.e., agents at the top level).

\section{Results and Discussion}

\subsection{The Role of the Board in A Company - The Indonesian Context}

The spearhead of the organization's decision control system, when there is a separation between ownership and control, is in the hands of the board. Fama and Jensen (1983) state that boards have the power to hire terminate and compensate top-level decision-making managers. The authority to control top level decisions given to the board helps ensure the separation of the decision management and decision control functions at the top of the organization so that corporate governance can guarantee the survival of an organization.

Indonesia has its own rules for the system of corporate governance. In the general GCG Guidelines, issued by the National Committee for Governance Policy (2006), it is stated that the General Meeting of Shareholders (GMS) is a corporate organ that is the forum for shareholders to make important decisions relating to capital invested in the company and oriented to the company's business interests in the long run. This guideline also states that the GMS and/ or shareholders cannot intervene in the duties, functions and authorities of the boards of commissioners and directors. However, the limitations of this intervention do not reduce the authority of the GMS to replace or dismiss members of the board of commissioners and/or directors. According to this description, it is clear that Indonesia has arranged the separation of functions between the ownership and the management of a company. In contrast to what was stated by Fama and Jensen (1983), boards in Indonesia have no authority to appoint or dismiss agents. The rules only state that the board of commissioners may suspend the board of directors. Permanent replacements and dismissals can only be carried out by the GMS.

The role played by the boards of companies in Indonesia is as a bridge between shareholders and management. The board functions in order to ensure that the company has been run well by the management so that the company's goals can be achieved (Lukviarman, 2016: 152). The very central role of the board triggered a debate about the its contribution to improving company performance, namely, in carrying out two different functions: the advisory and monitoring functions (Kim et al., 2014). The central role of the board in the company's strategic decision-making sometimes obscures the roles of control and monitoring, which it also plays (Lukviarman, 2016: 152). When carrying out its strategic role, the board acts as an advisor (advisory function), while, when controlling the company, it carries out the monitoring function.

The contradiction between these two functions is also experienced by boards in Indonesia who adhere to the twotier board system. The rules regarding boards in public companies in Indonesia are stipulated by Limited Company Law Number 40 of 2007 (Republic of Indonesia, 2007) and Regulation of the Financial Services Authority Number 33 of 2014. In this regulation, it is stated that "the Board of Directors is the Company's Organ, which has the authority and is fully responsible for the management of the Company in the interests of the Company, in accordance with the aims and objectives of the Company and represents the Company, both inside and outside the court in accordance with the provisions of the articles of association". Furthermore, it stated that "the Board of Commissioners is the Company's Organ that is responsible for conducting general and/ or specific supervision in accordance with the articles of association and giving advice to the Directors".

Based on the rules of the Law and the Financial Services Authority Regulations, as well as the GCG general guidelines by the National Committee for Governance Policy, it can be concluded that the monitoring and advisory functions are carried out by the board of commissioners. The board of commissioners as a corporate organ has a collective duty and responsibility to supervise and provide advice to the directors and ensure that the company implements GCG. However, the board of commissioners may not participate in making operational decisions (National Committee for Governance Policy, 2006: 13). The board of directors as a corporate organ has a collegial duty and responsibility in terms of managing the company. The effectiveness of the implementation of the duties of the board of directors requires the principle that the composition of the board of directors must be such that it allows decision making in an effective, precise and fast manner, and can act independently (National Committee for Governance Policy, 2006: 17). Based on this description, it can be concluded that the board of commissioners performs advisory and monitoring functions, while directors play a role in terms of decision-making function. This is of course different from the board model adopted by countries such as the U.S., Malaysia, or Singapore based on the one-tier board model.

\subsubsection{Qualifications of Members of the Board of Commissioners and Directors}

In carrying out their role, the competencies and capabilities of the members of the boards of commissioners and directors have a central role in determining the success of the company. Therefore, the process of proposing and selecting members 
of the boards of commissioners and directors to be carried out in the meeting of the GMS must be supported by the availability of adequate information about the candidates. The Limited Liability Company Law stipulates that members of the boards of commissioners and directors are elected by shareholders at the GMS. Capital market regulators currently have provisions regarding general requirements for candidates for members of the boards of commissioners and directors of issuers and public companies. However, in practice, the shareholders do not have detailed information about the qualifications and experience of the candidates for the two boards prior to the RUPS that will elect the candidates (Financial Services Authority, 2014b).

The determination of the qualifications of candidates for membership of the boards of commissioners and directors is very necessary in order that shareholders at the GMS have confidence that only candidates who have certain qualifications and sufficient experience will be selected. In the Indonesian Corporate Governance Roadmap report (Financial Services Authority, 2014b), the authority recommends, in accordance with international exemplary practices in the field of governance, that the rules or regulations be enacted that require that the qualifications of candidates for members of the boards of commissioners and directors must be determined and disclosed to shareholders at least at the time the GMS summons is published. In this regard, the existing provisions concerning the qualifications of candidates for membership of both boards need to be improved in order to accommodate the dynamics of developments in the field of governance and improve the performance of issuers and public companies.

\subsection{Optimization of Board Composition in Indonesia}

The quite central role of the board has been demonstrated by previous research. The research explores the relationship between board characteristics and company performance. One of the characteristics of the board is in terms of its size (number of members). The board size greatly influences the effectiveness of the decision-making process.

\subsubsection{The Board of Commissioners}

In the report 'The Indonesia Corporate Governance Manual', released by International Financial Corporation and Financial Services Authority, it is stated that the number of commissioners must be limited to the figures set in the company's articles of association. A board of commissioners having a small number of members is likely to cause the company to not be able to take advantage of the combined skills and breadth of experience of its members. Conversely, a board of commissioners having a large number of members will be impacted by difficulties with management and difficulties reaching consensus, so the implementation of tasks will take time and become more difficult. Therefore, there is a challenge in choosing the correct size of a board of commissioners given the need to find a balance between the two. The CG Guidelines in Indonesia state that the composition of the board of commissioners must be of sufficient size to suit the complexity of the company's business with regard to effectiveness in the decision making process.

The CG Guidelines by the National Committee for Governance Policy (2006) state that, in order to carry out the duties of the board of commissioners effectively, the following principles need to be adhered to. First, the composition of the board of commissioners must make it able to act independently and it must enable decisions to be made effectively and quickly. Furthermore, members of the board of commissioners must be professional, have integrity and the ability to carry out their functions properly including ensuring that the directors take into account the interests of all stakeholders. Finally, the supervisory and advisory functions of the board of commissioners cover preventive actions, corrections, and temporary dismissals.

In the GCG manual, it is stated that the board of commissioners must have at least one or member. When the board of commissioners consists of more than one member, then no member of the board of commissioners can act alone, but instead, acts on the basis of a joint decision of the board of commissioners. The Law of Limited Company Article 108 paragraph (5) states that companies whose business activities are related to the collection and/or management of public funds, companies that issue debt acknowledgment letters to the public, and public companies must have at least two members of the board of commissioners (2014 GCG Manual: 128).

Unlike in theU.S., where share ownershiptends to be widely distributed, many Indonesian public companies are controlled by majority shareholders, so the remaining ownership (which is widespread and comprises mostly minority shareholders) tends to have less information. Therefore, to overcome information gaps in order to effectively monitor management and defend against potential misuse by large shareholders, rules regarding independent commissioners have been drawn up. Independent commissioners have a very important role, so the regulations stipulate that the number of independent commissioners, according to CG regulations, is one third of the total number of members of the company's board of commissioners. The CG Indonesia Guidelines state that rules regarding independent commissioners are established to ensure that the control mechanism is effective and in accordance with laws and regulations. In addition to the number of members, the $\mathrm{CG}$ guidelines also require that one of the independent commissioners must have a background in accounting or finance. 


\subsubsection{Board of Directors}

Each company must have a board of directors responsible for managing the company on a day-to-day basis. The board of directors is responsible for the GMS. The Limited Company Law regulates the authority of the board of directors as well as the selection and dismissal mechanisms. As one of the organs in a limited company, the board of directors, according to the Law, has full authority and responsibility in managing the company in accordance with its objectives and interests as stipulated in the articles of association. Because of its central role, the Law, CG Guidelines and also the articles of association of the company strictly regulate the structure, role, authority, proposals, and the remuneration of the board.

Due to the fact the board of directors is the organ that has the authority to manage the company, the company needs to consider establishing the mechanism of the board of directors in making collective decisions, at least for important company decisions. When the board of directors is faced with important issues concerning the company, they will conduct discussions and coordination including with the main managers so that they can reach the best and most beneficial decisions for the company. Therefore, the number of the board of directors also plays an important role in helping to achieve company goals. Larger companies may need a board of directors to deal with more complex business models and organizational structures. Smaller companies usually have simpler business models and fewer resources to build formal structures (CG Manual, 2014: 186).

The Law of Limited Company does not explicitly stipulate certain qualifications that members of the board of directors must have. Their qualifications vary depending on business needs, company size and company needs. The CG Guidelines only provide general guidelines that board of directors members must be professional, have integrity and experience, and have the ability to carry out the tasks they are responsible for. Based on the description in the CG Manual and Guidelines in Indonesia, it is recognized that the number of members of the board of commissioners and board of directors plays an important role in corporate management. The problem faced is related to the optimum number of commissioners and directors on the boards so that the company's value is also at the optimum level.

\subsection{Study of The Effect of Board size on Company Performance}

\subsubsection{Basic Theory in Testing the Role of Board Size}

Theories about expert judgment state that everyone make imperfect judgments (Kirkebøen, n.d.). Even an expert can make mistakes. This justifies decision-making requiring the thinking of many experts so as to minimize the bias produced by one person. Kirkebøen (n.d.) concludes that, to overcome the bias, outsider involvement is needed to obtain more efficient results.

In Indonesia, it is stated that the decision making by the board is carried out collectively. The rules state that no member of the board of commissioners can act alone; all decisions are determined on the basis of a joint decision of the board of commissioners. Likewise the board of directors makes decisions collectively. In making decisions, the involvement of many parties may cause effectiveness problems. This includes free-riding issues, coordination, and problems related to schedule mismatches between members, as well as more time needed to make agreements (Titova, 2016). Therefore, theories related to organizational behavior, especially in the effectiveness of decision-making, are the basis in testing the role of board size in terms of performance.

\subsubsection{Effect of Board Size on The Company's Financial Performance}

Testing of board size's effect on the company's financial performance has been carried out by several researchers with mixed results. There are studies that show that board size has a negative effect on company performance in terms of ROA, Tobins Q, or ROE (Arosa et al., 2013; Majeed et al., 2020; Müller, 2014; Palaniappan, 2017). This indicates a weakness in terms of coordination, flexibility and poor communication between board members.

Conversely, there is also research that shows a positive effect of board size on company performance. Agustia (2017) demonstrates that the number of commissioners on a board has a significant effect on market reaction, which is measured by unexpected trading volume. Previous research found that board size has a significant effect on board independence and company performance (Rahman \& Saima, 2018; Rashid, 2018). By using regression analysis at five quantiles, board size was also found to have a positive and significant effect on performance at the four highest quantiles, while companies that were at the lower level of performance quintiles $(10 \%)$ tended not to react to board size (Shawtaria et al., 2016). This study shows that a larger board size does not affect companies with lower performance limits.

In contrast to previous studies, the studies conducted by Nor and Zawawi (2016) tried to calculate the optimal board sizes and relate them to two general measures of accounting performance, i.e., return on equity (ROE) and earnings per share (EPS). From a sample of listed companies in Malaysia, they found that the optimal board size did lead to better performance than companies with non-optimal board sizes but the results were not significant. They concluded that, although board size is a commonly used governance 
measure, determining the optimal amount to obtain superior performance may be difficult to understand.

The difference in influence of board size on performance, both positive and negative, prompted Titova (2016) to test the non-linear relationship between these two variables. Titova (2016) found that the number of U-shaped boards is reversed when associated with efficiency. The increasing size of boards can indeed contribute to creating higher efficiency through the expertise they have in carrying out their monitoring and advisory roles. The large number of boards also plays a role in helping to solve more complex problems. The banking industry tends to have bigger boards than nonfinancial companies. However, problems with free riding can also arise with large boards. Besides that, problems can also occur related to coordination, as well as the additional time needed when drafting an agreement when it involves more people. So, there is a trade-off between diversity and coordination. It can be assumed that complexity is an important determinant in determining the optimal board size (Titova, 2016).

\subsubsection{Effect of Board Size on Measures other than the Company's Financial Performance}

Several studies have tried to examine the relationship of the board size on performance in addition to financial performance. Among them are those related to the company's future risk (Haider \& Fang, 2016), export performance (Ilhan Nas \& Kalaycioglu, 2016), transparency and disclosure (Torchia \& Calabrò, 2016), dividend pay-out policy (Tahir, Masri, et al., 2020; Tahir, Rahman, et al., 2020) and the implementation of strategic management accounting (SMA) (Arunruangsirilert \& Chonglerttham (2017).

Haider and Fang (2016) conducted testing on board size in terms of the company's future risk. The results of his study found that board size negatively affects future firm risk when measured by the volatility of future stock prices and future cash flows. Board size is significantly related to company risk in the future. As the board size increases, the company's future risk decreases. So, a large board size will result in better performance. Ilhan Nas and Kalaycioglu (2016) tested the effect of board size on export performance. The results show that there is a significant positive relationship between board size and various measures of export performance. Other results show that the growing number of outside directors negatively affects export performance.

In contrast to the previous two studies, which tend to show the positive effect of board size on performance, the study by Torchia and Calabrò (2016) shows the opposite results. This study examined the relationship between the composition of the board of directors, including board size, and financial transparency and disclosure. The results show that there is a significant negative relationship between the relationship of board size and the level of transparency and financial disclosure.

Studies showing the effect of negative board size were also conducted by Arunruangsirilert and Chonglerttham (2017). The purpose of their study was to determine the relationship between corporate governance characteristics (including board size) and the implementation of strategic management accounting (SMA). The results of their study were to show that board size has a negative effect on participation in SMA and also on the application of SMA. Using stewardship theory, this study explains that companies with a larger board size tend to show less participation in SMA and less use of SMA. The smaller size of board of directors, which consists of company executives, is more efficient at managing strategic operations because the decisions are made faster than with a larger size of board of directors.

\subsubsection{Study of the Role of Board Size on Company Performance in Indonesia}

Studies conducted in Indonesia have measured the influence of the boards of commissioners on companies' financial performance. The results show that the size of the board of commissioners has a positive effect on financial performance (Lukviarman, 2016; Nugroho, 2016; Suteja \& Gunardi, 2016). Other studies test board size, but do not explain whether the boards in question are boards of directors or boards of commissioners or a combination of both. The results of another study indicate that board size also has a positive effect on performance (Robin \& Amran, 2016). Since the model used in Indonesia is a two-tier board, the study of the role of board size should measure the two types of boards separately, given that they play roles in corporate governance that have different functions. The board of directors carries out the strategic decision-making function, while the board of commissioners carries out the monitoring and advisory function.

\subsection{Study of Determinant Board Size}

With the previous studies having examined the effect of board size on various performance measures, then the questions arise: what is the optimal board size to produce optimal performance? What triggers changes in board size? This is of course similar to companies in Indonesia. Rules regarding the size of boards are not established by the rules, other than the minimum membership of a board of commissioners. Therefore, studies on optimal board sizes would still be interesting to carry out.

The board size is also determined by the complexity and leverage of the company. The performance in terms of Tobin's Q value will increase in line with the increasing size 
of boards in companies that require a greater level of advising namely companies with high levels of diversification and leveraging (Coles et al., 2007). The study also found that, for companies that conduct R\&D activities intensively, better board composition is derived from company insiders.

While studies on board size tend to be carried out in countries with a one-tier board system, the research conducted by Bohdanowicz (2015) tested board size in twotier systems such as those in Indonesia. The aim of his study was to describe the impact of various types of ownership on the size and diversity of the board of commissioners in the two-tier board model in Poland. Bohdanowicz's study found that there is a negative relationship between managerial ownership and the size of the board of commissioners; and a positive relationship with the diversity of the board of commissioners. Generally, the board of commissioners of a company with significant managerial ownership tends to be passive and owners who are concurrently managers tend to limit the role of the board of commissioners. The second result, related to companies with state ownership, found that there was a positive relationship between state ownership and the diversity and size of the board of commissioners. Companies with significant state ownership tend to show that this ownership has a negative affect on company performance. This is because state-owned companies work less efficiently than private companies due to the fact that board members are closely related to political connections and their competencies tend to be ignored. For this political reason, there is a tendency for the size of boards of commissioners in state enterprises to be large. Third, there is a positive relationship between financial investor ownership and the size of the supervisory board and a negative relationship between financial investor ownership and the diversity of the supervisory board. Financial investors supervise companies directly and place their representatives on the boards of commissioners. On the other hand, majority shareholders also place their representatives there. This causes the size of boards of commissioners in this type of company to become larger.

Financial ratio support, including liquidity, solvency, activities and good profitability, allows companies to have more board members than companies that experience financial problems. Compensation for the board members requires a not inconsiderable amount of money so companies experiencing financial distress cannot afford this compensation and therefore increasing the number of directors is not a good idea. The results of research on the composition of the board, especially the board of directors in Indonesia, indicate that liquidity, solvency, activity, and profitability affect the number of members of the board of directors significantly in quadratic form. In addition, the recommended number of directors for small companies is four directors, while for large companies, six to seven members of the board of directors are recommended (Krisnadewi \& Wirasedana, 2018).

\subsection{Simultaneous Relationship of Board Size and Company Performance}

Based on studies that have been conducted, it can be concluded that board size influences financial performance. At a certain level, board size shows a positive effect, but at other levels it shows a negative effect. Previous studies, both in Indonesia and outside Indonesia, tend to be conducted using testing of the linear relationship between these two variables. Logically, one can arrange the opposite relationship. In the initial formation, one certainly hopes that the board that is formed will affect the company's performance. Functionally, one can write this as 'company performance $=\mathrm{f}$ (board size)'. However, when the company's performance has been achieved, this will affect the size of the company's boards. Or 'board size $=\mathrm{f}$ (company performance)'. It can be logically stated that at the initial formation, the size of boards formed tends to be minimal. Over time, the company's improved performance will push the size of the company to become bigger and more complex. The larger and more complex business can trigger the need for boards that are even bigger. Based on this logic, it seems that further testing needs to be done of the relationship between board size and performance carried out simultaneously.

\section{Conclusions and Suggestions}

The separation of ownership and control functions has triggered agency conflicts between the owners and management (agent). To maintain the continuity of the company, the function of the decision process must be separated from the function of decision management and decision control. To bridge the owners and agents, a board is formed. The board is expected to carry out monitoring and advisory functions for the benefit of the owner. If, in a country with a rapidly developing capital market, agency conflict arises from the relationship between the owner and agent, then in Indonesia the conflict tends to originate from the relationship between the majority and the minority shareholders. This is facilitated by the formation of an independent board of commissioners.

This paper reviews the role of board size as part of the corporate governance system. Explanation begins with the origin of the formation of the board will help us understand about the roles assumed by board members. Understanding the role of this board is confirmed from the results of previous studies. Specifically for studies on board size in Indonesia, an understanding of the differences found in the two-tier board model helps us understand that the different functions of the board of commissioners and the board of 
directors require different test treatments from countries that adhere to one-tier systems.

Some of the rules related to boards in Indonesia include the Limited Company Law of 2007, the 2014 Financial Services Authority Regulation on the Board of Commissioners and Directors, and the 2006 Governance Policy Guidelines. The rules in Indonesia govern the minimum number of members of boards of commissioners as the owner's representatives. To resolve conflicts between majority and minority shareholders, the board of commissioners must also come from independent parties. Independent commissioners have a very important role so the regulations stipulate that the number of independent commissioners according to $\mathrm{CG}$ regulations is one third of the total number of members of the company's board of commissioners. For the board of directors, the $\mathrm{CG}$ guidelines do not regulate in detail its composition.

According to the rules, the number of members of the independent board will automatically follow the board size, especially boards of commissioners in the Indonesian context. The focus of the discussion in this paper is on board size. In accordance with the study that has been conducted, the empirical evidence shows that board size affects company performance. However, the evidence obtained is not conclusive. Some mentioned positive, negative, and also non-linear influences, namely, with an inverted U-shape. The results of the quantile regression analysis show that companies with low performance are not affected by the sizes of boards. In addition to the study on the influence on performance, previous studies also tried to identify the determinants of board size. Specifically, in terms of board size studies in Indonesia, studies that have been conducted tend to be focused on one board, and there may be a tendency to merge the sizes of these two boards into one when testing board size. Given the different functions, testing should be done separately. The results of the study on the influence of board size presented in this paper show a positive effect on company performance.

Overall, the study results tend to examine the linear effect between board size and performance. There is also research that tests the non-linear relationship between the two variables. In the final discussion of this paper, the authors briefly describe the possibility of a simultaneous relationship between board size and company performance. Therefore, future research needs to consider testing the simultaneous effect between board size and company performance (using a simultaneous equation approach).

A review of the relationship between board size and company performance is expected to provide the corporate governance literature with insights into optimizing the sizes of boards that can improve company performance, both in terms of boards of commissioners and boards of directors. Finally, this paper proposes the simultaneous testing of board size's relationship with company performance. The results of this study are expected to make a more real contribution about the effect of board size on company performance.

\section{References}

Agustia, D. (2017). The effect of ownership structure and board of commissioners on corporate social responsibility and market reactions. EKUITAS (Jurnal Ekonomi Dan Keuangan), 17(3), 376. https://doi.org/10.24034/j25485024.y2013.v17.i3.2258

Arosa, B., Iturralde, T., \& Maseda, A. (2013). The board structure and firm performance in SMEs: Evidence from Spain. Investigaciones Europeas de Dirección y Economía de La Empresa, 19(2013), 127-135. https://doi.org/10.1016/j. iedee.2012.12.003

Arunruangsirilert, T., \& Chonglerttham, S. (2017). Effect of corporate governance characteristics on strategic management accounting in Thailand. Asian Review of Accounting, 25(1), 85-105. https://doi.org/10.1108/ARA-11-2015-0107

Bohdanowicz, L. (2015). The impact of ownership structure on supervisory board size and diversity: Evidence from the polish two-tier board model. Procedia Economics and Finance, 23(2015), 1420-1425. https://doi.org/10.1016/S22125671(15)00429-3

Coles, J. L., Daniel, N. D., \& Naveen, L. (2007). Boards: Does one size fit all? Journal of Financial Economics, 87(2008), 329-356.

Fama, E. F. (1980). Agency problems and the theory of the firm. The Journal of Political Economy, 88(2), 288-307.

Fama, E. F., \& Jensen, M. C. (1983). Separation of Ownership and Control. Journal of Law and Economics, 26(2), 301-325.

Financial Services Authority (OJK). (2014). Governance Roadmap in Indonesia.

Financial Services Authority (OJK) Regulation Number 33 / POJK.04/2014 concerning the Board of Directors and Board of Commissioners of Issuers or Public Companies. (2014).

Haider, J., \& Fang, H.-X. (2016). Board size, ownership concentration and future firm risk. Chinese Management Studies, 10(4), 692-709. https://doi.org/10.1108/CMS-052016-0094

Ilhan Nas, T., \& Kalaycioglu, O. (2016). The effects of the board composition, board size and CEO duality on export performance. Management Research Review, 39(11), 1374-1409. https://doi.org/10.1108/MRR-01-2015-0014

International Financial Corporation (IFC) \& Financial Services Authority (OJK). (2014). The Indonesia Corporate Governance Manual.

Jensen, M. C., \& Meckling, W. H. (1976). Theory of the firm: Managerial behavior, agency costs and ownership structure. Journal of Financial Economics, 3(4), 305-360. https://doi. org/10.1016/0304-405X(76)90026-X 
Kim, K., Mauldin, E., \& Patro, S. (2014). Outside directors and board advising and monitoring performance. Journal of Accounting and Economics, 57, 110-131. https://doi. org/10.1016/j.jacceco.2014.02.001

Kirkebøen, G. (n.d.). Decision behaviour-improving expert judgement. Working Paper No. 169. http://www.ntnu.no/ documents/1261860271/1262022437/058_Kirkebooen - Expert judgement.pdf

Krisnadewi, K. A., \& Wirasedana, W. P. (2018). Optimum Board Size for Indonesian Public Companies. Jurnal Akuntansi Dan Keuangan, 20(2), 79-88. https://doi.org/10.9744/jak.20.2. 79-88

Law of the Republic of Indonesia Number 40 of 2007 concerning Limited Liability Companies, (2007).

Lukviarman, N. (2016). Corporate Governance: Towards Conceptual Strengthening and Implementation in Indonesia. In: R. N. Hamidawati (Ed.), Era Adicitra Intermediate.

Majeed, M. K., Jun, J. C., Zia-Ur-Rehman, M., Mohsin, M., \& Rafiq, M. Z. (2020). The board size and board composition impact on financial performance: An evidence from the Pakistani and Chinese's listed banking sector. Journal of Asian Finance, Economics and Business, 7(4), 81-95. https://doi. org/10.13106/jafeb.2020.vol7.no4.81

Müller, V. (2014). The impact of board composition on the financial performance of FTSE100 constituents. Procedia - Social and Behavioral Sciences, 109, 969-975. https://doi.org/10.1016/j. sbspro.2013.12.573

Nor, S. M., \& Zawawi, N. H. M. (2016). Is there an optimal board structure? An analysis using evolutionary- algorithm on the FTSE Bursa Malaysia KLCI. Procedia Economics and Finance, 35, 304-308. https://doi.org/10.1016/S2212-5671(16)00038-1

Nugroho, B. Y. (2016). Board governance of publicly listed companies in Indonesia: Towards sound corporate governance implementation. International Journal of Applied Business and Economic Research, 14(6), 3561-3573.

National Committee for Governance Policy (KNKG). (2006). General Guidelines for Indonesian Good Corporate Governance.

Palaniappan, G. (2017). Determinants of corporate financial performance relating to board characteristics of corporate governance in Indian manufacturing industry. European Journal of Management and Business Economics, 26(1), 67-85. https://doi.org/10.1108/EJMBE-07-2017-005

Rahman, M. M., \& Saima, F. N. (2018). Efficiency of board composition on firm performance: Empirical evidence from listed manufacturing firms of Bangladesh. Journal of Asian Finance, Economics and Business, 5(2), 53-61. https://doi. org/10.13106/jafeb.2018.vol5.no2.53

Rashid, A. (2018). Board independence and firm performance: Evidence from Bangladesh. Future Business Journal, 4(1), 34-49. https://doi.org/10.1016/j.fbj.2017.11.003

Robin, \& Amran, N. A. B. (2016). Implementation of good corporate governance mechanisms on family firm performance in Indonesia. Advanced Science Letters, 22(5-6), 1435-1438. https://doi.org/10.1166/as1.2016.6635

Shawtaria, F. A., Salemb, M. A., Hussaina, H. I., Alaeddina, O., \& Thabit, O. Bin. (2016). Corporate governance characteristics and valuation: Inferences from quantile regression. Journal of Economics, Finance and Administrative Science, 21, 81-88. https://doi.org/10.1016/j.jefas.2016.06.004

Suteja, J., \& Gunardi, A. (2016). CSR disclosure, corporate fundamental factors, corporate governance and profitability of banks in Indonesia. Social Sciences, 11(19), 4672-4676. https:// doi.org/10.3923/sscience.2016.4672.4676

Tahir, H., Masri, R., \& Rahman, M. (2020). Corporate board attributes and dividend pay-out policy: Mediating role of financial leverage. Journal of Asian Finance, Economics and Business, 7(1), 167-181. https://doi.org/10.13106/jafeb.2020. vol7.no1.167

Tahir, H., Rahman, M., \& Masri, R. (2020). Do board traits influence firms' dividend payout policy? Evidence from Malaysia. Journal of Asian Finance, Economics and Business, 7(3), 87-99. https://doi.org/10.13106/jafeb.2020.vol7.no3.87

Titova, Y. (2016). Are board characteristics relevant for banking efficiency? Evidence from the US. Corporate Governance, 16(4), 655-679. https://doi.org/10.1108/CG-09-2015-0124

Torchia, M., \& Calabrò, A. (2016). Board of directors and financial transparency and disclosure. Evidence from Italy. Corporate Governance, 16(3), 593-608. https://doi.org/10.1108/CG-012016-0019 